\title{
OBSERVATIONS ON THE LEUCOCYTOSIS PRODUCED BY THE TOXIN OF THE DIPHTHERIA BACILLUS, WITH ESPECIAL REFERENCE TO THE CHANGES WHICH FOLLOW THE INJECTION OF ANTI- TOXIN. ${ }^{1}$
}

\author{
By H. R. Dean, M.A., M.B.(Oxon.), M.R.C.P.(Lond.). \\ Research Fellow in Pharnacology to the Salter's Company.
}

IT has long been known that in many acute infective processes the onset of the disease is closely followed by a great increase in the number of leucocytes, and that this increase, in most cases, affects chiefly the cells of the polymorphonuclear type. It has also been observed that the leucocytosis is most marked in those cases in which a severe infection has attacked an individual having great power of resistance. The number of leucocytes found in any case depends on two factors-(a) the intensity of the infection; $(b)$ the resisting power of the individual.

The possible results have been tabulated by Cabot as follow:-

1. Infection mild : resistance good = small leucocytosis.

2. Infection less mild: resistance less good = moderate leucocytosis.

3. Infection severe : resistance good = very marked leucocytosis.

4. Infection severe: resistance poor $=$ no leucocytosis.

Leucocytosis accompanies the process of antitoxin formation, and while it is not possible from these data to suggest any closer relationship between the two phenomena, nevertheless the very close association of the two processes merits some consideration. Any attempt to investigate the effect of the administration of antitoxin on the number of the leucocytes is limited for practical purposes to a consideration of the changes which follow the use of diphtheria. antitoxin.

The condition of the blood in diphtheria has been investigated by many authors. The chief points on which the majority of investigators are agreed may be briefly stated :-

1. There is a great increase in the total number of leucocytes.

2. This increase chiefly affects the polymorphonuclear type of cell.

1 Received July 23, 1907. 
The available information is ably summarised by Cabot (1904).

In a general way the severest cases are found to show the greatest leucocytosis, but in a certain number of very severe cases the leucocytosis has been found to be absent.

Ewing (1895) examined fifty-three cases, in four of which there was no leucocytosis. In all four the degree of infection was very slight.

Billings (1896) found leucocytosis absent in two cases out of thirty-six ; one of these was the most severe of his whole series, the other was mild.

Morse (1895) found leucocytosis absent in four cases out of thirty, and of these four three were mild and one was severe.

The increase in the total number of leucocytes is, as a rule, considerable. The highest count recorded by Morse is 48,000 ; the highest recorded by Billings 38,600 .

With regard to qualitative changes, both Morse and Billings found that the polymorphonuclear cells averaged 80 per cent. Pitkianen $\left({ }^{10}\right)$ noted the disappearance of the eosinophile cells in the most severe cases, and suggested that an unfavourable prognosis might be based on their absence. Holmes (1905) demonstrated that the experimental injection of diphtheria bacilli and of diphtheria toxin was followed at first by a polynuclear, later by a mononuclear leucocytosis.

The changes which follow the use of antitoxin are less certainly known.

The injection of antitoxin, according to Cabot, has apparently no effect upon the leucocytes, except in the first twenty-four hours after its use. Immediately, i.e. within twenty minutes, after an injection the leucocytes are stated by Ewing to be considerably diminished, but the leucocyte curve does not reach normal any sooner than in cases in which no antitoxin is given, although it begins to fall in the majority of cases after the injection.

Engel (1897) found that antitoxin at first slightly increased the percentage of lymphocytes, and sometimes this increase was very marked. In one case the lymphocytes increased from 24 to 65 per cent. after antitoxin.

Gabritschewsky (1894) states that the increase of leucocytes is greatest in fatal cases. After antitoxin injections the leucocytosis steadily diminishes, as it does in convalescence, and the hæmocytometer is therefore, according to him, a useful means of gauging the success of treatment. Andrewes and Lloyd (1905) found that the high leucocytosis of well-reacting cases, after and during antitoxin treatment, steadily diminishes, the number of cells decreasing by 50 per cent. in three to four days.

In estimating the leucocytosis I have employed Strong's method.

Five c.mm. of blood withdrawn from the ear are diluted in a mixing bottle with $495 \mathrm{c.mm}$. of normal saline solution, to which is added a little methyl-violet. After twenty minutes $5 \mathrm{c.mm}$. of the mixture are blown by means of a specially calibrated pipette on to a glass slide. The drop is allowed to dry and is mounted in balsam. All the leucocytes contained in the drop are counted with $\frac{1}{6}$ in. objective and a squared eye-piece. Films were made in every case, and stained by Leishman's method. In nearly all cases 500 cells were counted.

In all six cases a moderate leucocytosis was present. The highest count was 28,000, the lowest 8000 . All the cases terminated favourably, and with the exception of Case 6 , which was mild, the infection was of moderate intensity. All cases showed a great increase of the polynuclear neutrophiles. In no case were myelocytes observed.

11—JL. OF PATH.-VOL. XII. 
TABle I.

OBSERVATION 1.-Child, ret. 4.-Faucial diphtheria. Length of History, five days.

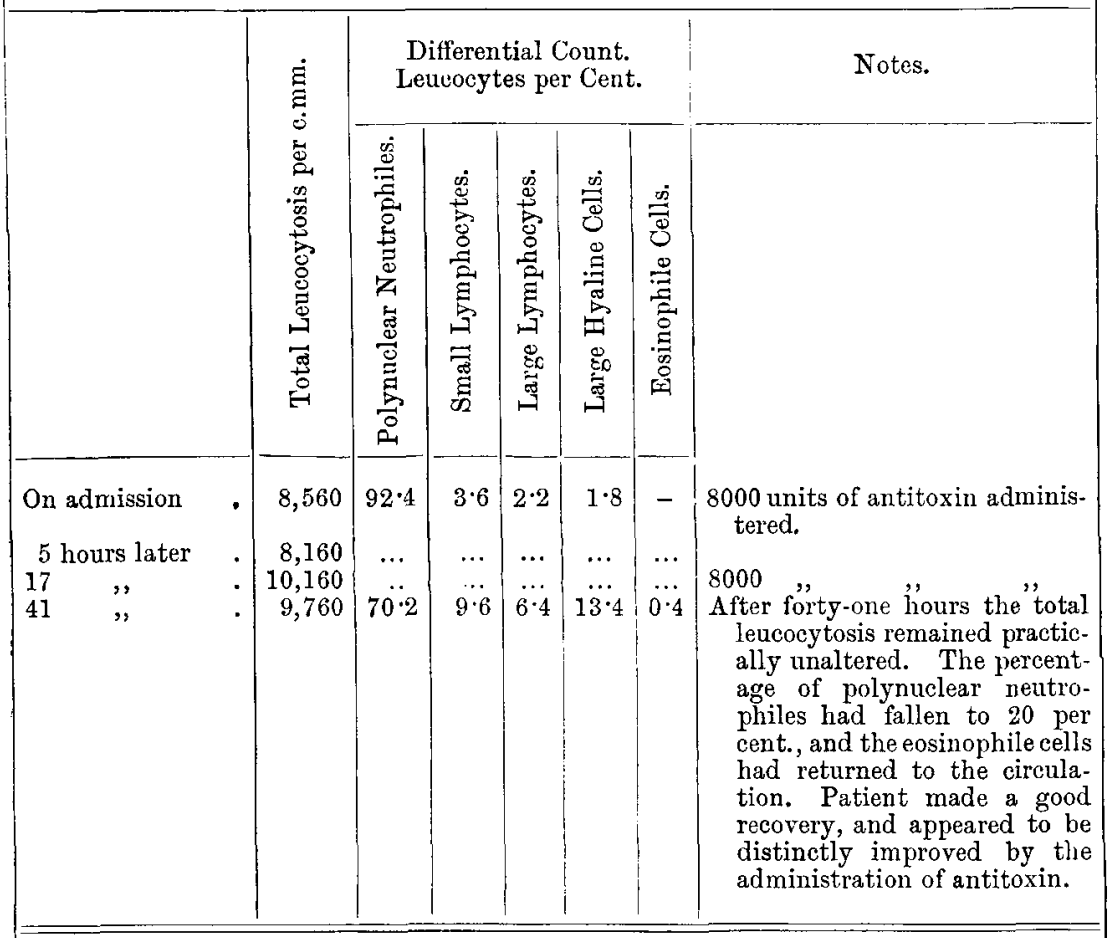

OBSERVATION 2.-Child, xt. 3.-Laryngeal diphtheria. Length of History, forty-eight hours.

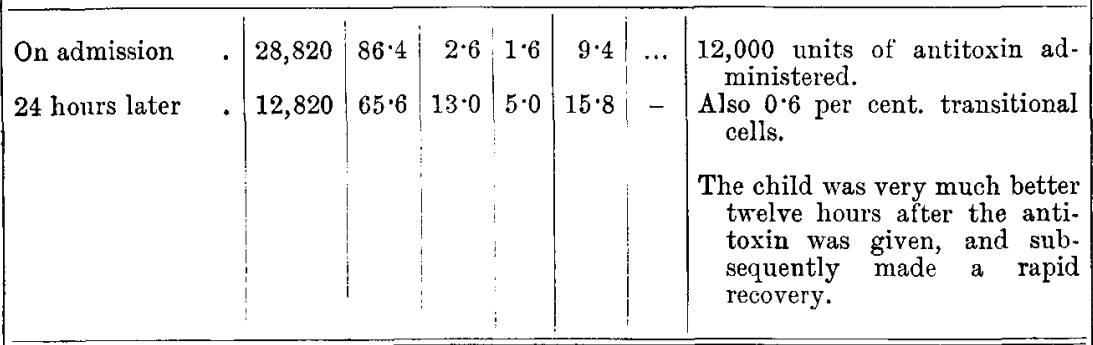

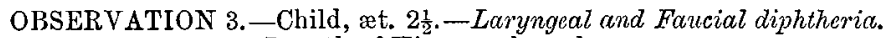
Length of History, three days.

\begin{tabular}{|c|c|c|c|c|c|c|c|c|}
\hline On admission & . & 19,160 & $82 \cdot 8$ & $8 \cdot 4$ & $1 \cdot 8$ & $6 \cdot 4$ & 0.3 & $\begin{array}{l}12,000 \text { units of antitoxin ad- } \\
\text { ministered. }\end{array}$ \\
\hline 17 hours later & . & 17,820 & $83 \cdot 2$ & $11 \cdot 8$ & $1 \cdot 6$ & $2 \cdot 6$ & 0.8 & $10,000 \quad, \quad,$, \\
\hline$"$, & . & 16,620 & 73.0 & $13 \cdot 0$ & $5 \cdot 2$ & $6 \cdot 2$ & $2 \cdot 6$ & $\begin{array}{l}\text { In this case the child showed } \\
\text { distinct signs of improvement } \\
\text { about thirty hours after the } \\
\text { first dose of antitoxin. Sub. } \\
\text { sequent progress of case un- } \\
\text { eventful. }\end{array}$ \\
\hline
\end{tabular}




\section{Table I.-Continued.}

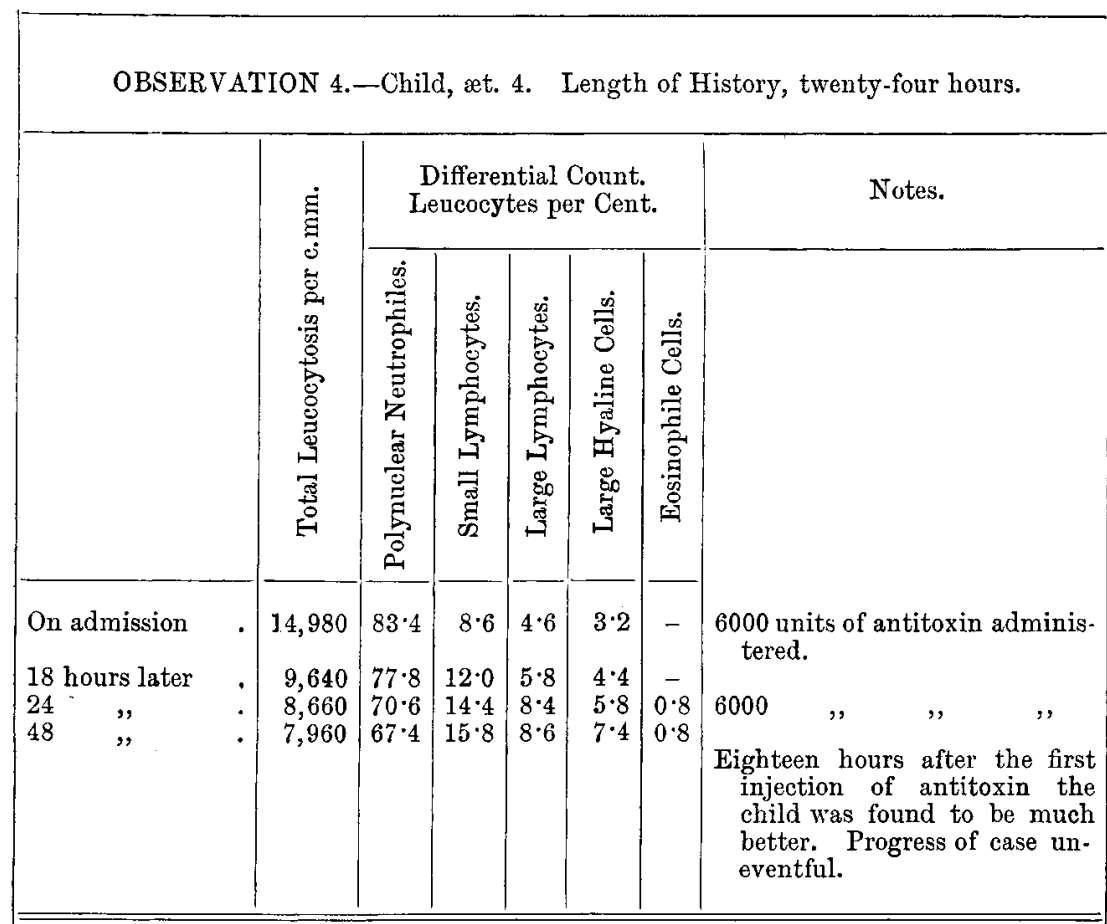

OBSERVATION 5.-Child, æt. 4.-Laryngeal, Faucial, and Nasal diphtheria. Length of History, three days.

\begin{tabular}{|c|c|c|c|c|c|c|c|c|}
\hline On admission & • & 15,280 & $90 \cdot 8$ & $5 \cdot 4$ & $2 \cdot 4$ & $1 \cdot 4$ & - & $\begin{array}{l}10,000 \text { units of antitoxin ad- } \\
\text { ministered. }\end{array}$ \\
\hline 1 hour later & , & 16,680 & $89 \cdot 6$ & $5 \cdot 8$ & $2 \cdot 8$ & $1 \cdot 8$ & - & \\
\hline , & - & 15,800 & $87 \cdot 4$ & $6 \cdot 8$ & $3 \cdot 2$ & $2 \cdot 6$ & - & \\
\hline 12 & . & 14,660 & $88 \cdot 4$ & $6 \cdot 6$ & $3 \cdot 2$ & $1 \cdot 6$ & $0 \cdot 2$ & 10,000 \\
\hline 24 & . & 16,340 & $86 \cdot 6$ & $7 \cdot 8$ & $3 \cdot 4$ & $2 \cdot 2$ & 0 & \\
\hline 48 & . & 14,920 & $83 \cdot 4$ & $10 \cdot 2$ & $3 \cdot 8$ & $2 \cdot 4$ & 0.2 & $\begin{array}{l}\text { The patient improved consider- } \\
\text { ably during the second day } \\
\text { after admission, and the sub- } \\
\text { sequent progress of the case } \\
\text { was uneventful. }\end{array}$ \\
\hline
\end{tabular}

OBSERVATION 6.-Child, æt. 6.-Faucial diphtheria. Length of History, seventy-two hours.

\begin{tabular}{|ll|r|r|r|r|r|r|r|}
\hline On admission & $\cdot$ & 12,960 & $87 \cdot 0$ & $8 \cdot 0$ & $3 \cdot 2$ & $1 \cdot 8$ & - & 8000 units of antitoxin given. \\
12 hours later & $:$ & 13,400 & $88 \cdot 8$ & $6 \cdot 4$ & $3 \cdot 0$ & $1 \cdot 8$ & - & \\
$24 \quad "$ & $*$ & 11,940 & $82 \cdot 2$ & $9 \cdot 4$ & $4 \cdot 6$ & $3 \cdot 4$ & $0 \cdot 4$ & In this case the infection was \\
$48 \quad$ mild. The child gradually \\
\end{tabular}


Eosinophile cells were only observed in one case (3) before the administration of antitoxin. In two cases only was the administration of antitoxin followed by a marked fall in the leucocytosis, and in these cases it is of interest to note that the length of history was comparatively short-in one case twenty-four hours, in the other forty-eight hours. In the remaining four cases no very marked diminution in the leucocytosis followed the administration of antitoxin In several other cases the blood was counted before the administration of antitoxin, and again at intervals varying from five minutes to one hour after the injection of the antitoxin. In no case was any immediate change apparent. I have been unable to find any change in the blood during the first hour following the administration of antitoxin.

A consideration of the conditions makes it evident that it is difficult to draw conclusions from an investigation of ordinary cases of diphtheria. In the first place, the length of history must always be a matter of some uncertainty. Again, in many, if not all, cases the leucocyte reaction is probably partly due to the action of other organisms, notably the pyogenic cocci. To obviate these difficulties experiments were performed with rabbits, and the leucocytosis was produced by the injection of known quantities of diphtheria toxin.

The strength of toxin employed was such that $\frac{1}{2} \frac{1}{00}$ to $\frac{1}{1} \frac{1}{0}$ of a c.c. would kill a guinea-pig in four days; $\frac{1}{20}$ c.c. of the toxin was found to be neutralised by 2000 units of antitoxin.

As has been pointed out by Dudgeon and Ross (1905), the number of leucocytes varies enormously in individual rabbits, and no average figure can be relied upon. In each of these experiments the blood was counted immediately before the injection of toxin. It is unnecessary to give a lengthy description of the blood cells found in the rabbit, but a few points may be mentioned which have a direct bearing on these experiments. The total leucocytosis varies as a rule between 1500 and 3500 per c.mm. The small lymphocytes are, as compared with the human blood, very numerous, and the finely granular polymorphonuclear cells are correspondingly decreased in number. The granules of the polymorphonuclear finely granular cells are larger and more distinct than are those of the corresponding cells in human blood, and they are, moreover, distinctly eosinophilic. They resemble, in fact, at first sight, the eosinophilic cells of the human blood. They are, moreover, readily distinguished from the coarsely granular polymorphonuclear cells by the size of the granules. The granules of these latter cells are in the rabbit's blood enormous, and stain with Leishman's stain a dull copper colour. The other peculiar features of the rabbit's blood have no direct bearing on these experiments. 
TABle II.

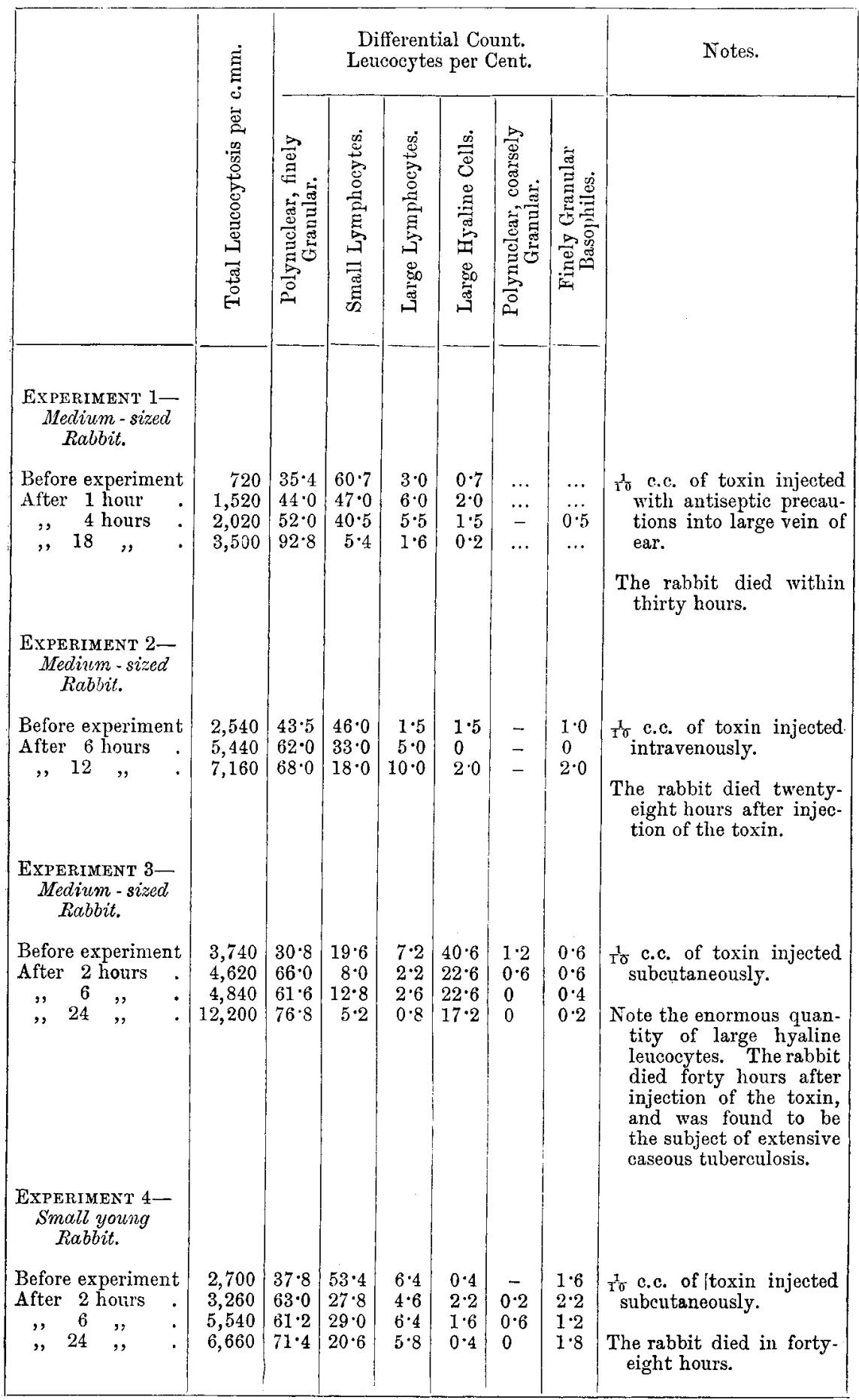


The above four cases represent a very severe and acute toxæmia produced by the diphtheria toxin. The result of the injection of the diphtheria toxin is to produce a great increase in the total number of leucocytes, which is apparent one hour after the injection of toxin. With this dose of toxin the maximal leucocytosis was observed about twelve hours after the injection of the toxin. There was an enormous. increase in the proportion of the polynuclear neutrophiles. In some of the experiments the disappearance of the eosinophilic cells was very noticeable.

In two of these experiments films were made from the blood at intervals of five, ten, twenty, forty, and sixty minutes after the injection of the toxin. No change was noted during the first half-hour. During the second half-hour a slight increase of polymorphonuclear cells could be demonstrated. There was no increase of eosinophilic cells.

It may be noted that these enormous doses produced a prompt leucocytic reaction, and nothing comparable to the recorded absence of leucocytosis in very severe cases was observed. The red cells showed very marked degenerative changes, and polychromatophilia was well marked in every case in the later counts. No myelocytes were observed. It will be seen that neither in these experiments nor in the experiments summarised in Table III. was any period of hypoleucocytosis observed.

TABLE III.

\begin{tabular}{|c|c|c|c|c|c|c|c|c|}
\hline & \multirow{2}{*}{ 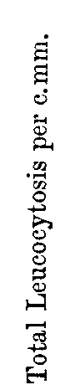 } & \multicolumn{6}{|c|}{$\begin{array}{l}\text { Differential Count. } \\
\text { Leucoeytes per Cent. }\end{array}$} & \multirow[t]{2}{*}{ Notes. } \\
\hline & & 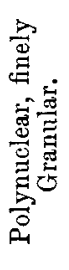 & 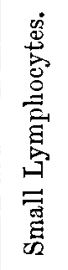 & 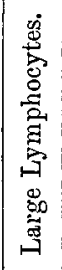 & 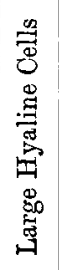 & 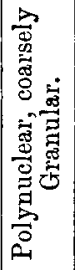 &  & \\
\hline $\begin{array}{l}\text { EXPERIMENT 5- } \\
\text { Medium - sized } \\
\text { Rabbit. }\end{array}$ & & & & & & & & \\
\hline Before experiment & 2,740 & $47 \cdot 8$ & $46^{\circ} 6$ & $2 \cdot 8$ & $1 \cdot 4$ & $1 \cdot 0$ & 0.4 & $\begin{array}{l}\frac{1}{10} \text { c.c. toxin injected, and } \\
\text { simultaneously } 4000 \text { units } \\
\text { of antitoxin. }\end{array}$ \\
\hline After 4 hours & 2,860 & $46 \cdot 8$ & $45 \cdot 8$ & $2 \cdot 6$ & $1 \cdot 8$ & 0.6 & $2 \cdot 2$ & $\begin{array}{l}\text { Also } 0.2 \text { per cent. of transi- } \\
\text { tional cells. }\end{array}$ \\
\hline $\begin{array}{lll}\prime & 12 & \end{array}$ & $\begin{array}{l}2,360 \\
2,920\end{array}$ & $\begin{array}{l}51 \cdot 4 \\
49 \cdot 2\end{array}$ & $\begin{array}{l}43 \cdot 4 \\
42 \cdot 6\end{array}$ & $2 \cdot 2$ & $\begin{array}{l}1 \cdot 8 \\
2 \cdot 4\end{array}$ & $\begin{array}{l}0.2 \\
0.4\end{array}$ & $\begin{array}{l}1 \cdot 0 \\
1 \cdot 8\end{array}$ & $\begin{array}{l}\text { The simultaneous admin- } \\
\text { istration of antitoxin } \\
\text { completely protected the } \\
\text { rabbit, which remained } \\
\text { apparently in perfect } \\
\text { health throughout the } \\
\text { experiment. The leu- } \\
\text { cocytes remained practic- } \\
\text { ally unaltered through- } \\
\text { out. }\end{array}$ \\
\hline
\end{tabular}


TABLE III.-Continued.

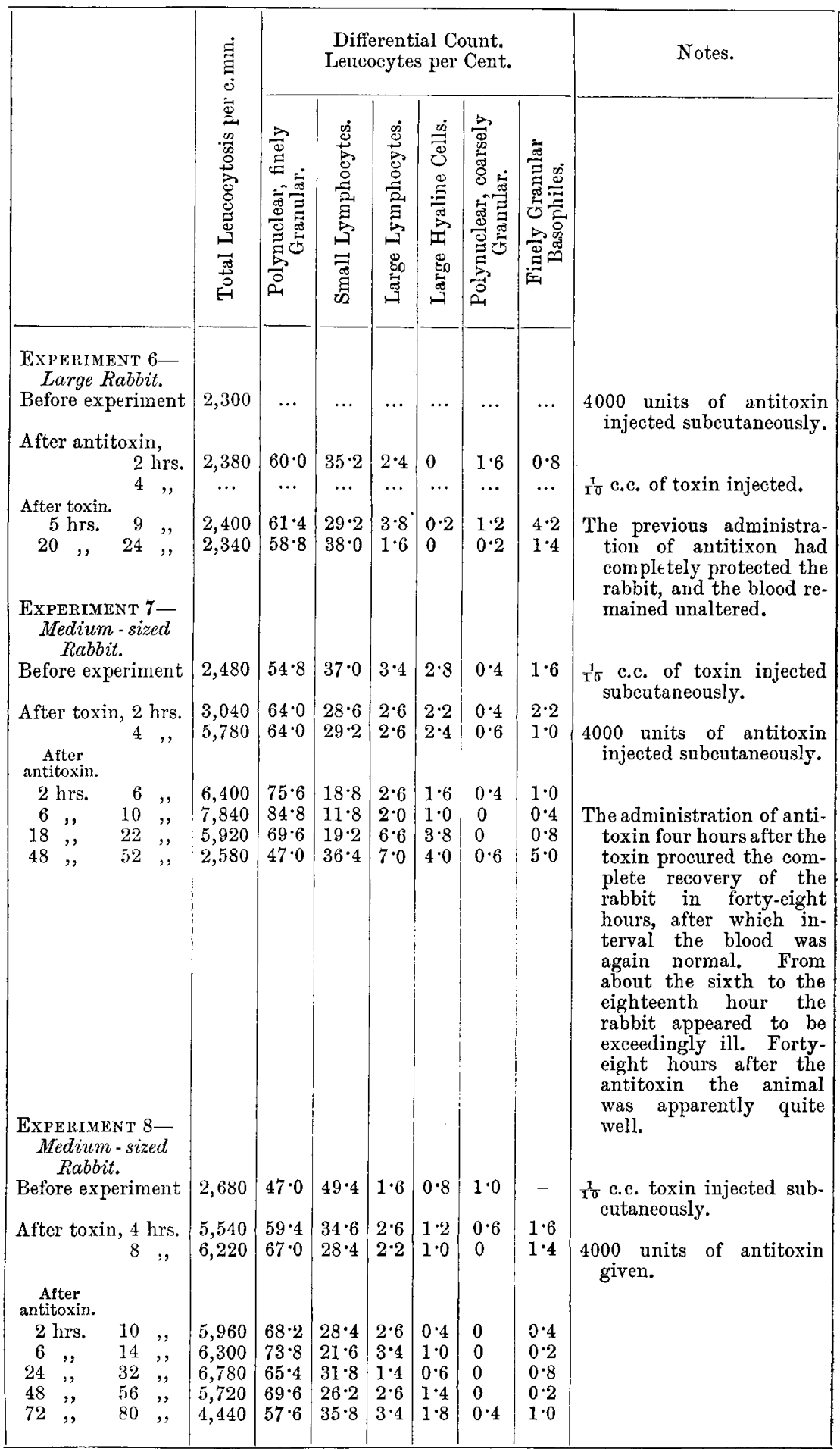


In experiment No. 8 the rabbit began to show signs of illness four hours after the toxin, and became rapidly worse, thirty-two hours after the toxin and twenty-four hours after the antitoxin it was very ill and seemed likely to die. Fifty-six hours after the toxin and forty-eight hours after the antitoxin it had enormously improved, and at the time of the last count appeared to be well. It was found dead on the sixth day. Death was very probably due to cardiac failure.

In this experiment eight hours were allowed to elapse before antitoxin was given, and time was given for large quantities of the toxin to become combined. The antitoxin acted no doubt by neutralising the still uncombined toxin, and the rabbit's life was prolonged by several days. Almost the full degree of leucocytosis had been produced at the time when the antitoxin was given, and the antitoxin had no appreciable effect in reducing the number of leucocytes. This experiment is probably comparable to those cases of diphtheria with severe toxæmia in which antitoxin is not given until late. In such cases antitoxin can only affect the uncombined toxin. The leucocytosis is only reduced when the antitoxin is given early.

TABLE III.-Continued.

\begin{tabular}{|c|c|c|c|c|c|c|c|c|}
\hline &  & & $\begin{array}{r}\text { Diffe } \\
\text { Leuco }\end{array}$ & renti & $\begin{array}{l}\text { al Co } \\
\text { per }\end{array}$ & $\begin{array}{l}\text { unt. } \\
\text { Cent. }\end{array}$ & & Notes. \\
\hline & 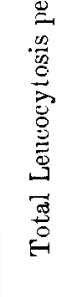 &  & 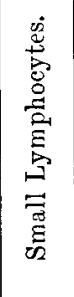 & 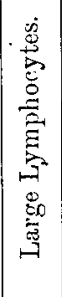 & 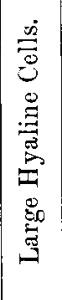 & 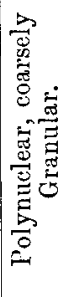 & 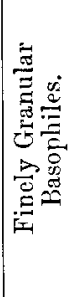 & \\
\hline $\begin{array}{l}\text { EXPERIMENT 9- } \\
\text { Medium - sized } \\
\text { Rabbit. }\end{array}$ & & & & & & & & \\
\hline Before experiment & 3,120 & $57 \cdot 4$ & $39 \cdot 6$ & $1 \cdot 6$ & 0.6 & $0 \cdot 4$ & 0.4 & 1\% c.c. of toxin injected \\
\hline $\begin{array}{l}\text { After toxin, } 4 \text { hrs. } \\
12 ", \\
\text { After } \\
\text { antitoxin. }\end{array}$ & $\begin{array}{l}4,660 \\
6,780\end{array}$ & $\begin{array}{l}70 \cdot 8 \\
69 \cdot 2\end{array}$ & $\begin{array}{l}25 \cdot 6 \\
26^{\circ} 6\end{array}$ & $\begin{array}{l}2 \cdot 2 \\
2 \cdot 8\end{array}$ & $\mid \begin{array}{l}0.8 \\
1.2\end{array}$ & $\begin{array}{l}0 \cdot 2 \\
0\end{array}$ & $\begin{array}{l}0.4 \\
0.2\end{array}$ & $\begin{array}{l}4000 \text { units of antitixon } \\
\text { given. }\end{array}$ \\
\hline $\begin{array}{cc}4 \mathrm{hrs} . & 16 \\
24, " & 36\end{array}$ & $\begin{array}{l}6,540 \\
6,780\end{array}$ & $\begin{array}{l}83 \cdot 8 \\
75 \cdot 2\end{array}$ & $\begin{array}{l}14 \cdot 0 \\
19 \cdot 8\end{array}$ & $\begin{array}{l}1 \cdot 4 \\
3 \cdot 0\end{array}$ & $\mid \begin{array}{l}0.8 \\
0.8\end{array}$ & $\begin{array}{l}0 \\
0.9\end{array}$ & $\begin{array}{l}0 \\
1 \cdot 2\end{array}$ & $\begin{array}{l}\text { The rabbit died within } \\
\text { forty-eight hours after } \\
\text { the toxin. The admin- } \\
\text { istration of antitoxin } \\
\text { twelve hours after the } \\
\text { toxin was too late to } \\
\text { produce any improve- } \\
\text { ment, and the antitoxin } \\
\text { lad no effect on the } \\
\text { leucocytosis. }\end{array}$ \\
\hline
\end{tabular}


From these experiments it appears that by the injection of the pure toxin derived from the diphtheria bacillus a leucocytosis is produced which is in every way similar to that observed during the course of a case of diphtheria in the human subject. There is a large increase in the total number of leucocytes which is associated with an enormous increase in the polynuclear finely granular cells.

It seems probable that the leucocytosis in a case of diphtheria is the reaction to the presence of a toxin in the blood, and that it is the result of a positive chemiotaxis exerted by the toxin on the polynuclear neutrophile.

It will be noticed even in those cases in which the toxin was injected intravenously, and in which death occurred in a few hours, that a large leucocytosis was produced. No instance of failure of the leucocytes to react to the stimulus was observed. Probably we may regard the degree of leucocytosis as some evidence of the degree of toxæmia.

The simultaneous injection of a sufficient amount of antitoxin completely inhibited the leucocytosis. The toxin was completely neutralised, and together with destruction of its toxic power its power for evuking leucocytosis was removed. When the antitoxin was given four hours after the injection of the toxin its effect was still apparent, but only after eighteen hours had elapsed. When an interval of eight or twelve hours was allowed, no effect on the leucocytosis could be observed. In referring to the above recorded cases of diphtheria occurring in children it will be noted that a distinct reduction in the number of leucocytes was observed in the two cases of the series in which the shortest interval had elapsed between the onset of the symptoms and the administration of antitoxin.

The leucocytosis is certainly a manifestation of the toxiemia, and its rapid decrease may be regarded as an indication of the neutralisation of the toxin. It is probable that a distinct drop in the number of the leucocytes, coupled with a diminution in the number of polynuclear neutrophiles occurring in a case of diphtheria, within twenty-four hours after the administration of the antitoxin, may be taken as an indication that the disease has been treated in good time, and that an adequate dose of antitoxin has been employed. A rapid decrease in the leucocytosis may be regarded as favourably affecting the prognosis.

The leucocytosis is the reaction of the individual against the toxin, and is possibly the means by which the antitoxic bodies are produced and the toxins neutralised. In this connection it is of interest to notice that the leucocytosis begins with the onset of the infection, and tends to wane with the period of convalescence. With the timely injection of antitoxin the necessity for the production of antitoxin within the body ceases and the leucocytosis is inhibited or arrested.

The main conclusions may be thus briefly stated :-

1. After the experimental injection of diphtheria antitoxin there is a great increase in the total number of leucocytes; this increase is 
due to the appearance in the blood of enormous numbers of polymorphonuclear cells.

2. After the injection of the diphtheria toxin degenerative changes can be demonstrated in both the white and red cells. In the latter polychromatophilia is often well shown. A reduction in the number, or a complete disappearance of the coarsely granular eosinophilic cells, is, as a rule, observed.

3. In this series of experiments no myelocytes were seen.

4. The changes in the blood which follow the experimental injection of diphtheria toxin are similar to those seen in cases of diphtheria occurring in the human subject.

5. A dose of antitoxin which, when given simultaneously with the toxin, completely protects the animal under observation, prevents the appearance of the leucocytosis.

6. When a sufficient dose of antitoxin is administered within a short time of the injection of toxin the number of leucocytes rapidly falls to normal.

7. When a considerable interval has been allowed to elapse between the injection of toxin and the injection of antitoxin no reduction in the leucocytosis occurs.

8. In two of the above recorded cases of diphtheria in children the interval between the onset of the disease and the employment of antitoxin was relatively short, and in these cases a considerable reduction in the leucocytosis appeared to follow the use of antitoxin.

9 . No reduction in the number of leucocytes was observed in the four cases in which a relatively longer time had elapsed between the onset of symptoms and the use of antitoxin.

10. A marked reduction in the leucocytosis occurring within the first twenty-four hours after the injection of antitoxin probably indicates a good prognosis.

11. A sufficient dose of antitoxin completely protects the blood cells from degenerative changes.

These experiments were performed in the Physiological Laboratory and in the Jenner Clinical Laboratory at St. Thomas's Hospital, and I have to record my thanks to Dr. L. S. Dudgeon for much advice and very valuable assistance.

\section{REFERENCES.}

1. Andrewes AND Lloyd . Article "Diphtheria" in "A System of Medicine," Allbutt and Rolleston, second edition, London, 1905, vol. i. p. 999.

2. Billivgs . . . . . Med. Rec., N.Y., 1896, April 25, No. 17, vol. xlix. p. 577.

3. CABOT . . . . . "A Guide to the Clinical Examination of the Blood," fifth edition, London, 1904, pp. $97,213$. 
4. Dudgeon and Ross . . Trans. Path. Soc. London, 1906, vol Ivii. part 2, p. 160.

5. ENGel . . . . . . . Verhandlungen des Vereins f. innere Med. zu Berlin, 1897, Jahrgang xvi. S. 121.

6. Ewing. . . . . . . New York Med. Journ., 1895, vol. lxii. p. 163.

7. Gabritschewsky . . . Ann. de l' Inst. Pasteur, Paris, 1894, tome viii.

pp. 673-685.

8. Holmes . . . . . . Guy's Hosp. Rep., London, 1905, vol. lix. p. 155.

9. Morse. . . . . . Boston Med. and Surg. Journ., 1895, vol. cxxxii. pp. 228, 253.

10. Pitkianen . . . . . (Cited by Cabot, supra.) 